Ivanka Ristić, Aleksandar Zdravković, Aleksandra Mičić, Dragana Marković Nikolić, Nebojša Ristić*

Vocational High School for Technology and Art, Leskovac, Serbia
Scientific paper

ISSN 0351-9465, E-ISSN 2466-2585

UDC:677.21:677.027.4

doi:10.5937/zasmat2001060R

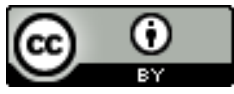

Zastita Materijala 61 (1)

$60-68$ (2020)

\title{
Ecological alternatives to conventional dyeing of cotton with reactive dyes
}

\begin{abstract}
Cotton dyeing is usually performed by reactive dyes by exhaustion method. Great quantities of salts and alkalis used in the formulation of dyeing bath eventually get into the watercourses and negatively affect the environment. In this work, studied are the possibilities of reducing salt and alkali concentrations in the dyeing bath in order to reduce water pollution after the dyeing process and soap washing. The obtained results show that the alternative procedures are environmentally more favorable, which is demonstrated by reduced values chemical oxygen demand. High level of dye fixation and fastness was achieved, while the colour intensity was slightly lower in comparison with standard samples.
\end{abstract}

Keywords: cotton, reactive dyes, ecology, waste water, chemical oxygen demand.

\section{INTRODUCTION}

From the first appearance of reactive dyes for cotton in 1956 this class of dyes has had a more and more important place in dyeing textiles due to the high color fastness, a wide range of shades and various methods of application. In recent years, the consumption of these dyes is 4 to 5 times higher than that of other dyes. Although widely used for dyeing of cotton and other cellulose fibers, reactive dyes have serious drawbacks, primarily as a result of their chemical structure. With the use of reactive dyes, parallel to the reaction of the dye with the fibers, another reaction occurs, the reaction with water dye hydrolysis. Although the reaction with fiber is a lot faster than with water, in the final distribution of dye between fiber and water, about $10-40 \%$ of dyes are not fixated, leaving one part of this dye in the solution and the other part is transferred to fiber simply as a substantive dye which may adversely affect the fastness if left on the fiber. The most important parameters which influence the distribution of dye

${ }^{*}$ Corresponding author: Nebojša Ristić

E-mail: bojana1998@ptt.rs

Paper received: 24. 07. 2019.

Paper corrected: 23. 10. 2019.

Paper accepted: 20. 12. 2019.

Paper is available on the website: www.idk.org.rs/journal are the so-called variable parameters [1]: concentration of salt, concentration of alkalis, liquor ratio, dyeing temperature and dyeing time.

The reactive exhaustion dyeing makes up about $70 \%$ of all dyeing methods requiring the use of significant amounts of salts and alkalis which enter water streams after dyeing, threatening the environmental situation. Moreover, soap washing after dyeing to remove the unfixed dye requires high consumption of water, chemicals and energy [2].

For these reasons, researchers around the world are working on finding new dyes and methods of application in order to reduce the impact of man on the environment with the aim to protect nature and people. In this regard several approaches are at their disposal [3]:

- development of reactive dyes,

- development of dyeing machines,

- chemical modification of cotton fibers before dyeing,

- the use of biodegradable organic compounds in dyeing bath, and

- treatment of dyeing waste water.

In recent years, synthesis of dyes having two or more reactive groups is a special trend in the development of reactive dyes $[4,5]$. These dyes are characterized by bulky molecules with a big 
chromogen usually combined with two reactive groups. Bifunctional dyes exhibit higher substantivity with lower amounts of electrolyte and have higher fixation degree. More than two reactive groups do not increase fixation efficiency due to adverse side effects on dye solubility, substantivity and migration.

Cationic chemical modification of cotton before dyeing has been widely investigated as an efficient treatment for higher yield of dye on cotton [6-8]. The treatment of cotton with cationic compounds leads to changes in free surface energy and reactivity of fiber surface, zeta potential and dyeing capability. Intensity of anionic dyes on cationized cotton increases progressively with concentration of cationic agent as a consequence of reaction of the agent with methyl hydroxyl groups on cellulose C6 atom. Reducing the negative potential and increasing the free surface energy reduces ion-ion repulsion between anionic dyes and negatively charged groups on the fiber.

From the ecological point of view on the application of reactive dyes on cotton it is important to develop such dyeing procedures which would minimize the consumption of chemicals in the stages of dyeing and soap rinsing because residual dye and chemicals in dyeing liquor after dyeing and soaping contribute in high values to the pollution indicators of waste water - chemical oxygen demand (COD) and biological oxygen demand (BOD) [9].

The World Bank estimates that $17-20 \%$ of industrial pollution comes from the dyeing and finishing of textiles and 72 toxic chemicals have been identified in waste water from textile dye houses. The dyeing of cotton with reactive dyes is in the first place. For these reasons, on the basis of EU initiatives for more efficient textile dyeing, the so-called sustained dyeing is promoted, which means:

- application of processes with lower consumption of energy, water and time,

- automatization of controlled dyeing temperature and time,

- reducing dye content in effluent, and

- chemical and biological treatment of dyeing effluent.

Due to big ecological issues in textile dyeing industry the legislation regarding dyeing houses waste water quality [10] is promoted and procedures with modified environment friendly formulations of dyeing bath for reactive cotton dyeing have been suggested $[11,12]$.
In recent years, alternative washing processes for the removal of hydrolyzed reactive dye have been intensively studied. These procedures lower water consumption, reduce or completely reject the use of chemicals and reduce the process duration [13-15]. The research shows that the removal of hydrolyzed dye occurs within the first $15 \mathrm{~min}$ of washing and the conventional washing process in 5 baths could be successfully replaced by "hot washing"- a process with 3 baths at $98^{\circ} \mathrm{C}$ without the use of chemicals.

The aim of this work is to identify and estimate the possibilities for improvement in reactive cotton dyeing by exhaustion method under conditions compatible with the industrial process and emphasizing the reduced consumption of chemicals. In this work, the standard dyeing temperature of $56^{\circ} \mathrm{C}$ in test series 1 and 2 was replaced by a temperature of $66^{\circ} \mathrm{C}$ to achieve a suitable color intensity. The test samples of the first series were dyed with a reduced amount of $\mathrm{NaCl}$, while test samples of the second series were dyed with a reduced amount of $\mathrm{Na}_{2} \mathrm{CO}_{3}$, in order to decrease the impact of waste water on the environment.

\section{EXPERIMENTAL}

\subsection{Materials}

The cotton fabric with surface mass of $204 \mathrm{~g} / \mathrm{m}^{2}$ was used in tests. The fabric was factory prepared for dyeing.

In this work the following commercial reactive dyes were used without further purification: Bezaktiv gelb S-3R $150 \%$, Bezaktiv rot S-3B 150\% and Bezaktiv blau S-GLD 150\% (Bifunctional dyes - Mono Chloro Triazine/Vinyl sulfone), by Bezema, Switzerland, and Drimaren brilliant blau K-BL and Drimaren brilliant rot K-BG (Monofunctional dyes Difluoro chloro pyridine), by Clariant, Switzerland.

The dyeing of specimens was performed according to standard and testing procedures.

Table 1 gives sample designations.

Dyeing of the samples was carried out by All-in procedure in the apparatus Ahiba with the vertical movement of the materials (TYP G7B) in a $90 \mathrm{~min}$ at a bath ratio of 1:40.

After dyeing the samples were washed 3 times with distilled water and subjected to washing in soap solution of the following formulation: $1 \mathrm{~g} / \mathrm{dm}^{3}$ anionic washing agent; $1 \mathrm{~g} / \mathrm{dm}^{3} \mathrm{Na}_{2} \mathrm{CO}_{3}$, at $90^{\circ} \mathrm{C}$ for $15 \mathrm{~min}$ and rinsed again with distilled water. The samples were air-dried at room temperature. 
Table 1. Sample designations

Tabela 1. Oznake uzoraka

\begin{tabular}{|c|c|c|c|c|c|}
\hline Dye & $\begin{array}{c}\text { Sample } \\
\text { designation }\end{array}$ & $\begin{array}{c}\text { Temperature } \\
\left({ }^{\circ} \mathrm{C}\right)\end{array}$ & $\begin{array}{l}\mathrm{c}(\mathrm{NaCl}) \\
\left(\mathrm{g} / \mathrm{dm}^{3}\right)\end{array}$ & $\begin{array}{c}\mathrm{c}\left(\mathrm{Na}_{2} \mathrm{CO}_{3}\right) \\
\left(\mathrm{g} / \mathrm{dm}^{3}\right)\end{array}$ & $\begin{array}{c}\mathrm{c}(\mathrm{NaOH}, 32.5 \%) \\
\left(\mathrm{cm}^{3} / \mathrm{dm}^{3}\right)\end{array}$ \\
\hline \multirow{3}{*}{$\begin{array}{l}\text { Bezaktiv gelb } \\
\text { S-3R } 150 \%\end{array}$} & 1 & 56 & 80 & 15 & 1.5 \\
\hline & 1.1 & 66 & 50 & 15 & 1.5 \\
\hline & 1.2 & 66 & 80 & 7 & 1.5 \\
\hline \multirow{3}{*}{$\begin{array}{l}\text { Bezaktiv rot } \\
\text { S-3B 150\% }\end{array}$} & 2 & 56 & 80 & 15 & 1.5 \\
\hline & 2.1 & 66 & 50 & 15 & 1.5 \\
\hline & 2.2 & 66 & 80 & 7 & 1.5 \\
\hline \multirow{3}{*}{$\begin{array}{l}\text { Bezaktiv blau } \\
\text { S-GLD 150\% }\end{array}$} & 3 & 56 & 80 & 15 & 1.5 \\
\hline & 3.1 & 66 & 50 & 15 & 1.5 \\
\hline & 3.2 & 66 & 80 & 7 & 1.5 \\
\hline \multirow{3}{*}{$\begin{array}{l}\text { Drimaren brilliant } \\
\text { blau K-BL }\end{array}$} & 4 & 56 & 80 & 15 & 1.5 \\
\hline & 4.1 & 66 & 50 & 15 & 1.5 \\
\hline & 4.2 & 66 & 80 & 7 & 1.5 \\
\hline \multirow{3}{*}{$\begin{array}{l}\text { Drimaren brilliant } \\
\text { rot K-BG }\end{array}$} & 5 & 56 & 80 & 15 & 1.5 \\
\hline & 5.1 & 66 & 50 & 15 & 1.5 \\
\hline & 5.2 & 66 & 80 & 7 & 1.5 \\
\hline
\end{tabular}

\subsection{Methods}

All color values were measured on Spectraflash SF600X reflection spectrophotometer (Datacolor, USA) with a light source D65 and observation angle $10^{\circ}$. Before measurement the samples were folded twice to get four layers of the fabric and the reflection was measured on four different spots on the sample surface. Color intensities (K/S) were determined at wavelengths of maximum absorption for the dyes used: Bezaktiv gelb S-3R $150 \%$ at $440 \mathrm{~nm}$; Bezaktiv rot S-3B $150 \%$ at $550 \mathrm{~nm}$; Bezaktiv blau S-GLD $150 \%$ at $620 \mathrm{~nm}$; Drimaren brilliant blau K-BL at $620 \mathrm{~nm}$ and Drimaren brilliant rot K-BG at $520 \mathrm{~nm}$, according to Kubelka-Munk equation:

$$
\frac{K}{S}=\frac{(1-R)^{2}}{2 R}
$$

where:

$K$ - absorption coefficient, $S$ - light scattering coefficient, $R$ - reflection of the D65/10 light.

Fixation degree of the reactive dye was calculated from the equation 2 :

$$
F=\frac{\left(\frac{K}{S}\right)_{T}}{\left(\frac{K}{S}\right)_{0}} \cdot 100
$$

where subscript $T$ refers to the fabric treated with soap solution and subscript 0 to untreated fabric, immediately after dying.
Testing of dyeing wash fastness was done according to ISO 105 C10:2006 norm.

The $\mathrm{pH}$ value of a solution was regulated by the addition of $\mathrm{Na}_{2} \mathrm{CO}_{3}$ and $\mathrm{NaOH}$ and measured before and after dyeing on the HANNA digital $\mathrm{pH}$ meter (model HI 2209).

COD is oxygen quantity equivalent to dichromate consumed for oxidation of organic matter and a part of inorganic matter that can be oxidized, in a specific volume of tested surface or waste water. COD can be considered as an approximate measure of theoretical oxygen demand, i.e. as a quantity of oxygen consumed for complete oxidation of organic compounds to inorganic products.

\section{Open reflux titrimetric method}

Method description: The waste water is refluxed with a strong oxidizing agent, potassium dichromate, $\mathrm{K}_{2} \mathrm{Cr}_{2} \mathrm{O}_{7}$ in $50 \% \mathrm{H}_{2} \mathrm{SO}_{4}$ and after $2 \mathrm{~h}$, titrating with the standard solution of ferrous ammonium sulfate, the surplus of non reacted dichromate is determined.

A part of water sample was refluxed at $148^{\circ} \mathrm{C}$ in the presence of $\mathrm{H}_{2} \mathrm{SO}_{4}$ with a known quantity of $\mathrm{K}_{2} \mathrm{Cr}_{2} \mathrm{O}_{7}$ and $\mathrm{Ag}_{2} \mathrm{SO}_{4}$ as a catalyst in strong $\mathrm{H}_{2} \mathrm{SO}_{4}$ for a specified period where by a part of dichromate was reduced by organic matter. The remaining dichromate was, after cooling, titrated with fero ammonium sulfate with feroin as the indicator. The blank sample, where the tested water was replaced 
with distilled water, was tested parallel. COD value was calculated from the quantity of reduced dichromate $(1 \mathrm{~mol}$ of dichromate is equivalent to $1.5 \mathrm{~mol}$ of oxygen).

\section{Calculation:}

$$
\operatorname{COD}\left(\mathrm{mg} / \mathrm{dm}^{3}\right)=\frac{(a-b) M \times 8000}{V}
$$

\section{Where}
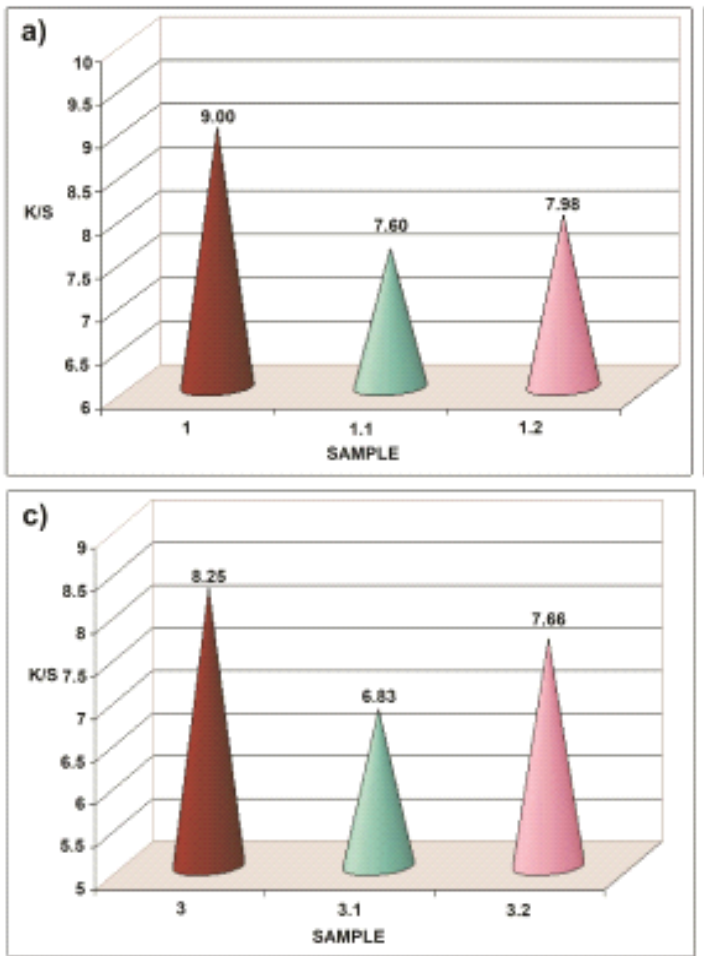

$a$ and $b$ are the volumes of ferrous ammonium sulfate consumed for the titration of blank sample and the sample with waste water, $\mathrm{cm}^{3}$,

$M$ - molarity of ferrous ammonium sulfate,

$V$ - volume of the test sample, $\mathrm{cm}^{3}$.

\section{RESULTS AND DISCUSSION}

\subsection{Color intensities}

Figure 1 show color intensities of dyes.
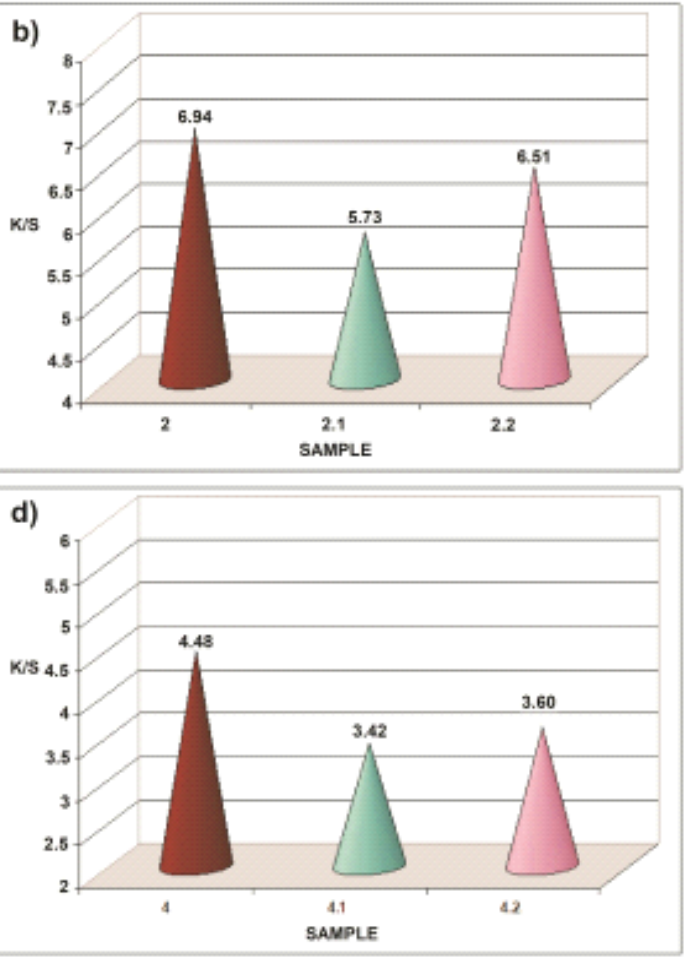

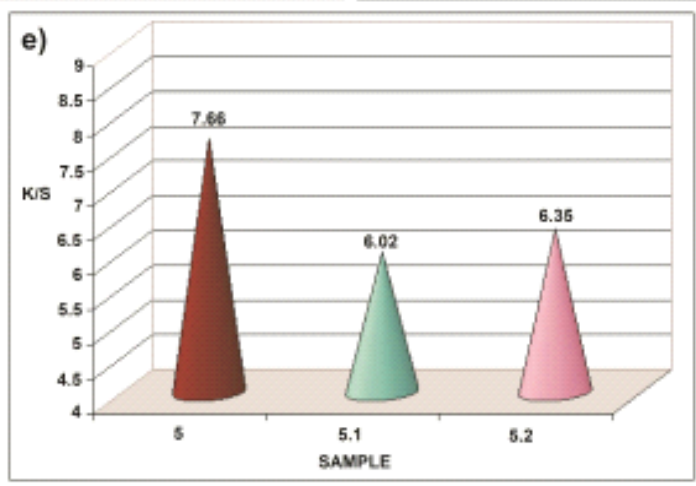

Figure 1. Color intensity of: Bezaktiv gelb S-3R 150\% (a), Bezaktiv rot S-3B 150\% (b), Bezaktiv blau SGLD 150\% (c), Drimaren brilliant blau K-BL (d) and Drimaren brilliant rot K-BG (e)

Slika 1. Intenzitet obojenja: Bezaktiv gelb S-3R 150\% (a), Bezaktiv rot S-3B 150\% (b), Bezaktiv blau SGLD $150 \%$ (c), Drimaren brilliant blau K-BL (d) i Drimaren brilliant rot K-BG (e)

From the graphic presentations it is clearly visible that samples dyed according to standard procedure have the highest color intensities. Standard dyeing formulation consists of suggested concentrations of $\mathrm{NaCl}$ and $\mathrm{Na}_{2} \mathrm{CO}_{3}$ - electrolytes that provide conditions for dye transferring from the solution to fiber surface and for dye fixation creating a covalent bond. In this work, a variant of traditional dyeing method, known as "All-in", was used, where all components of the dyeing solution were added at the start of dyeing. This dyeing method enables dye exhaustion in the presence of 
salt $(\mathrm{NaCl})$ and formation of dye-fiber covalent bond in the presence of alkali (a mixture of $\mathrm{Na}_{2} \mathrm{CO}_{3} / \mathrm{NaOH}$ ). If this dyeing method could be replaced with a process which includes increasing of temperature, in order to form a dye-fiber covalent bond, with reduced quantities of salt and alkalis, the following benefits could be achieved: cheaper dyeing process, reduction of reactive dye hydrolysis, simultaneous dyeing of wool-cotton blends using the same reactive dye and other.

In this work, standard dyeing temperature of $56^{\circ} \mathrm{C}$ was replaced with the temperature $66^{\circ} \mathrm{C}$ in test variants 1 and 2 , in order to reach matching dye intensity comparable with the standard process. Increased temperature of 10 degrees should increase the cotton cellulose/reactive dye reaction rate without affecting the dye hydrolysis. The dyeing of samples series with reduced content of both electrolytes $\left(\mathrm{NaCl}\right.$ and $\left.\mathrm{Na}_{2} \mathrm{CO}_{3}\right)$ in the bath was not carried out due to the significantly lower color intensity compared to the standard process, which is impractical for industrial dyeing.

Test samples dyed with bifunctional dyes with reduced $\mathrm{NaCl}$ concentration $(\downarrow 37.5 \%)$ - samples $1.1,2.1$, and 3.1 had lower color intensities by 15 $17 \%$ (Figs. 1a, b and c). Also, with monofunctional dyes, used according to the same procedure, a decline of dye intensities (K/S) by 21 and $24 \%$ was recorded. It can be concluded that increasing the dyeing bath temperature for $10^{\circ} \mathrm{C}$, in order to increase the concentration of $\mathrm{Cell}^{-} \mathrm{O}^{-}$ions, compensates the reduction of $\mathrm{NaCl}$ concentration to achieve high color intensity on the samples of cotton fabric.

On test samples dyed with reduced $\mathrm{Na}_{2} \mathrm{CO}_{3}$ concentration $(\downarrow 53 \%)$, the changes of color intensity were also observed depending on the functionality of the used dyes. With bifunctional dyes, the intensity reduction was $6-11 \%$, while with monofunctional dyes it was 17 and $20 \%$. The results obtained indicate that bifunctional dyes have lower sensitivity to reduced amount of alkalis compared to monofunctional dyes when dyeing temperature was increased by $10^{\circ} \mathrm{C}$. These results reflect higher reactivity of bifunctional dyes which are exhausted and fixated in a higher degree than monofunctional dyes under the applied experimental conditions.

Absorption of dyes on fiber and creation of dyefiber covalent bond depends on the ratio of physical-chemical and electro-chemical forces at the cotton/liquor interface. The main parameters affecting these interactions involve dyeing bath $\mathrm{pH}$, electrolyte concentration and dyeing bath temperature. At the water solution/cotton interface, the surface of cellulose fiber is negatively charged due to dissociation of cellulose carboxyl groups. The cotton negative charge (zeta potential) is neutralized by the addition of salt $(\mathrm{NaCl})$ by which adsorption of dye in its molecular form is facilitated. Moreover, $\mathrm{NaCl}$ in the solution increases dye chemical potential thus increasing its substantivity, meaning higher exhaustion degree resulting in the highest color intensity on the samples dyed using standard formulation. Increasing solution temperature significantly compensates salt deficiency in test formulations. In systems with reduced amount of $\mathrm{NaCl}$ (1.1-5.1), despite higher temperature, lower dye substantivity resulted in lower dye utilization, i.e. observed were greater changes in color intensities compared to test formulation 2 because salt is the most important for the absorption of reactive dyes, especially in systems with high liquor ratio. With test formulation 2 where $\mathrm{Na}_{2} \mathrm{CO}_{3}$ was reduced, higher sensitivity was observed with less reactive - monofunctional dyes where higher temperature compensates, to some degree, the reduced ionization of cellulose $\mathrm{OH}$ groups due to lower solution alkalinity.

In Table 2 given are fixation degrees of reactive dyes. From the results obtained, small changes in fixation degree of test samples can be observed compared to corresponding standards, which means that in these dyeing systems sufficient concentration of ionized cellulose $\mathrm{OH}$ groups existed to react covalently with dyes. Bifunctional reactive dyes have higher reactivity than monofunctional so the fixation degree was higher by $\approx 10 \%$.

\section{Table 2. Fixation degree of reactive dyes}

Tabela 2. Stepen fiksiranja reaktivnih boja

\begin{tabular}{|l|c|c|}
\hline \multirow{2}{*}{ Dye } & $\begin{array}{c}\text { Sample } \\
\text { designation }\end{array}$ & $\mathbf{F}$ (\%) \\
\hline \multirow{3}{*}{ Bezaktiv gelb S-3R 150\% } & 1 & 90.9 \\
\cline { 2 - 3 } & 1.1 & 92.1 \\
\cline { 2 - 3 } Bezaktiv rot S-3B 150\% & 1.2 & 91.1 \\
\cline { 2 - 3 } & 2 & 92.2 \\
\cline { 2 - 3 } & 2.1 & 90.6 \\
\hline \multirow{3}{*}{ Bezaktiv blau S-GLD 150\% } & 2.2 & 89.5 \\
\cline { 2 - 3 } & 3 & 88.1 \\
\cline { 2 - 3 } & 3.1 & 88.5 \\
\hline \multirow{3}{*}{ Drimaren brilliant blau K-BL } & 4 & 86.3 \\
\cline { 2 - 3 } & 4.1 & 82.4 \\
\cline { 2 - 3 } & 4.2 & 80.3 \\
\hline \multirow{3}{*}{ Drimaren brilliant rot K-BG } & 5 & 80.0 \\
\cline { 2 - 3 } & 5.1 & 83.5 \\
\cline { 2 - 3 } & 5.2 & 83.1 \\
\hline
\end{tabular}

\subsection{Wash fastness}

During reactive dyeing of cotton one part of the dye is not fixed on to the fiber but reacts with water. One part that reacted with water (hydrolyzed dye) remains in the dyeing bath while the other part 
passes to the fiber under dyeing conditions as a substantive dye.

Table 3. Wash fastness

Tabela 3. Postojanost na pranje

\begin{tabular}{|l|c|c|}
\hline \multicolumn{1}{|c}{ Dye } & $\begin{array}{c}\text { Sample } \\
\text { designation }\end{array}$ & Fastness \\
\hline \multirow{3}{*}{ Bezaktiv gelb S-3R 150\% } & 1 & 4 \\
\cline { 2 - 3 } & 1.1 & 4 \\
\hline \multirow{3}{*}{ Bezaktiv rot S-3B 150\% } & 1.2 & $3-4$ \\
\cline { 2 - 3 } & 2 & 4 \\
\hline \multirow{3}{*}{$\begin{array}{l}\text { Bezaktiv blau S-GLD } \\
\text { 150\% }\end{array}$} & 2.1 & 4 \\
\hline \multirow{2}{*}{$\begin{array}{l}\text { Drimaren brilliant blau K- } \\
\text { BL }\end{array}$} & 3 & 4 \\
\cline { 2 - 3 } & 3.1 & 4 \\
\hline \multirow{nyy}{*}{$\begin{array}{l}\text { Drimaren brilliant rot K- } \\
\text { BG }\end{array}$} & 4.2 & 4 \\
\cline { 2 - 3 } & 4.2 & 4 \\
\cline { 2 - 3 } & 5 & 4 \\
\hline
\end{tabular}

Complete removal of non fixed hydrolyzed dye by soap treatment determines dyeing wash fastness. Based on the results for the fastness (Table 3) it can be concluded that alternative dyeing methods do not make worse wash fastness of dyes used, i.e. in the system dye-cotton covalent bonds are established that steadily fixate dye to the fiber.

\section{3. $\mathrm{pH}$ of a solution}

The regulation of the proper $\mathrm{pH}$ of a solution is of great importance in the cotton dyeing with reactive dyes since dye fixation is carried out in an alkaline medium. In an alkaline solution, the hydroxyl groups of the cellulose ionize and react in an ionic form with the functional groups of the reactive dyes. For reactive dyes, the $\mathrm{pH}$ value is additionally important because it affects the degree of dye hydrolysis in the dyeing bath, which leads to a reduction in color depth and a change in the color tone. The optimal $\mathrm{pH}$ value of the bath for dyeing with reactive dyes (11-12) provides a sufficient amount of Cel-O- for the reaction of dye with the fiber. Before dyeing, the following $\mathrm{pH}$ values were measured: standard series $\mathrm{pH} 11.25$; test series 1 $\mathrm{pH}$ 11.38; test series $2 \mathrm{pH} 11.20$. From the obtained results, it can be concluded that the initial $\mathrm{pH}$ value in all systems was in the optimal range. Insufficient alkalinity of the solution does not provide a sufficient number of ionized groups CelO- for reaction with the dye, while too many negative sites on the cellulose repel the negative ions of the dye and cause worse dye exhaustion. Measurements after dyeing indicate a slight decrease in bath alkalinity due to the fiber and alkali reaction (Table 4).

\section{Table 4. $\mathrm{pH}$ of a solution after dyeing}

Tabela 4. $\mathrm{pH}$ rastvora nakon bojenja

\begin{tabular}{|c|c|c|c|c|c|}
\hline $\begin{array}{c}\text { Sample } \\
\text { designation }\end{array}$ & $\begin{array}{c}\mathrm{pH} \text { after } \\
\text { dyeing }\end{array}$ & $\begin{array}{c}\text { Sample } \\
\text { designation }\end{array}$ & $\begin{array}{c}\mathrm{pH} \text { after } \\
\text { dyeing }\end{array}$ & $\begin{array}{c}\text { Sample } \\
\text { designation }\end{array}$ & $\begin{array}{c}\mathrm{pH} \text { after } \\
\text { dyeing }\end{array}$ \\
\hline 1 & 10.98 & 1.1 & 11.10 & 1.2 & 10.68 \\
\hline 2 & 10.97 & 2.1 & 11.09 & 2.2 & 10.66 \\
\hline 3 & 10.96 & 3.1 & 11.10 & 3.2 & 10.63 \\
\hline 4 & 10.90 & 4.1 & 11.10 & 4.2 & 10.66 \\
\hline 5 & 10.88 & 5.1 & 11.09 & 5.2 & 10.65 \\
\hline
\end{tabular}

\subsection{Chemical oxygen demand of dye solutions}

Chemical oxygen demand means oxygen concentration required for oxidation of all organic compounds in water and indicates the degree of waste water pollution.

Figure 2 show graphically COD values for the solutions of used reactive dyes at the end of the dyeing process. From the results shown, high values of chemical oxygen demand are observed what can be attributed to the presence of dyes and electrolytes. The dyeing baths for dyeing samples with standard formulations always showed the highest COD values, which can be attributed to high concentrations of salt and soda ash used in dyeing, because more than $70 \%$ of COD values come from chemical auxiliary agents [16].

The solutions prepared with testing formulations had lower chemical oxygen demand, i.e. lower pollution. Among all dyes the least COD values were observed for solutions designated as test 1 . The reduction of COD in solutions of bifunctional dyes with reduced $\mathrm{NaCl}$ concentration was $55-60 \%$, and in solutions of monofunctional dyes it was 50 and $70 \%$. Reactive dyes solutions prepared according to test 2 formulation had lower chemical oxygen demand compared to standard dyeing process, i.e. for bifunctional dyes by 14- 
$22 \%$ and for monofunctional dyes by 8 and $35 \%$ (Figs. 2d and e).

The pollution decrease of the solutions at the end of dyeing with test formulations can be attributed to corresponding lowering of $\mathrm{NaCl}$ and $\mathrm{Na}_{2} \mathrm{CO}_{3}$ amounts in test dyeing formulations, so less oxygen is needed for their oxidation. From the ecological point of view, the dyeing with alternative formulations using selected monofunctional and bifunctional dyes is environmentally more favorable giving solutions after dyeing with significantly lower chemical oxygen demand, i.e. pollution, and it can be considered that these procedures have a practical potential and they are in accordance with the principles of applying the best available technologies in the textile dyeing.
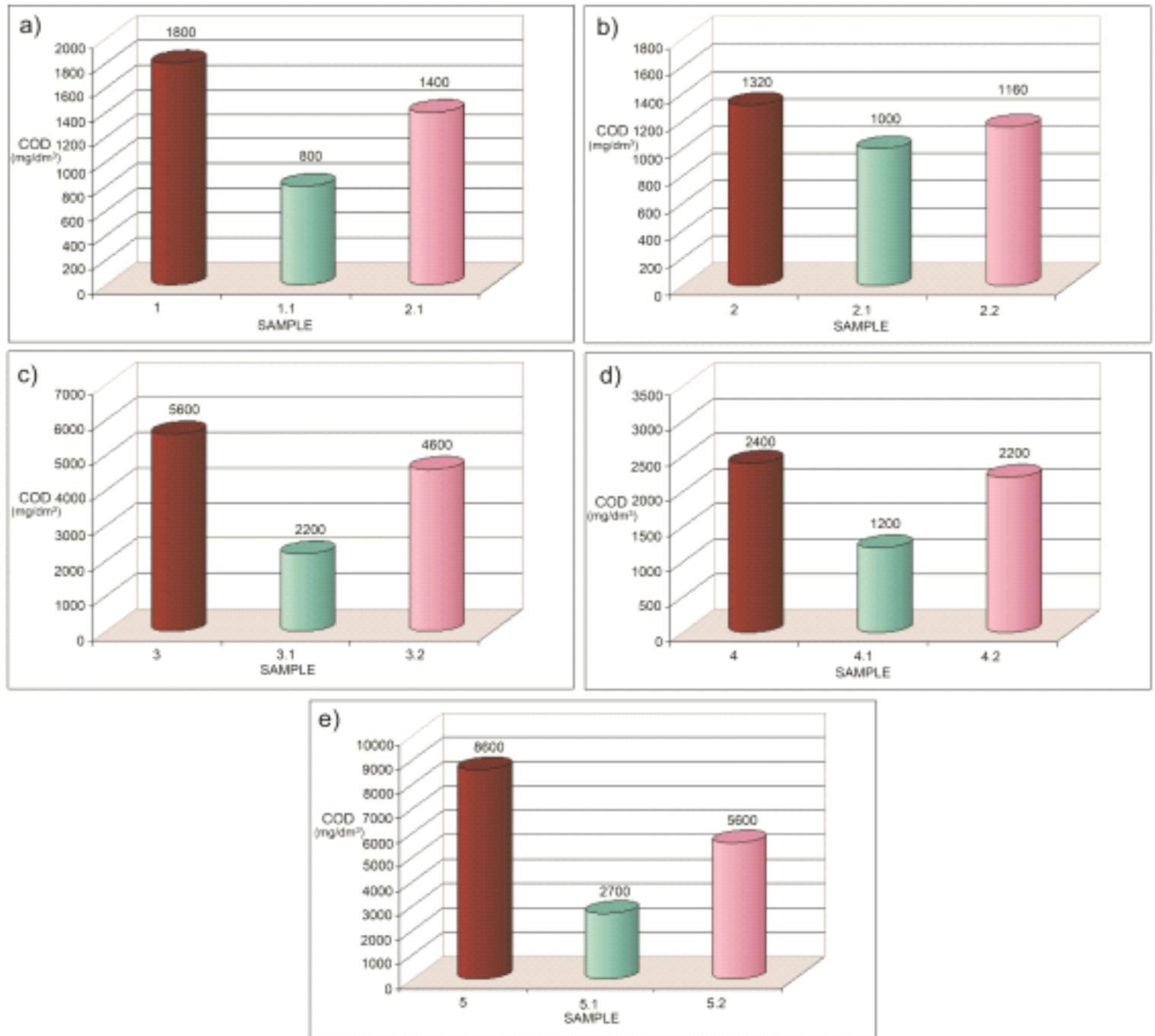

Figure 2. COD values for: Bezactiv gelb S-3R 150\% (a), Bezactiv rot S-3B 150\% (b), Bezactiv blau S-GLD $150 \%$ (c), Drimaren brilliant blau K-BL (d) and Drimaren brilliant rot K-BG (e)

Slika 2. HPK vrednosti za boju: Bezaktiv gelb S-3R 150\% (a), Bezaktiv rot S-3B 150\% (b), Bezaktiv blau S-GLD 150\% (c), Drimaren brilliant blau K-BL (d) i Drimaren brilliant rot K-BG (e)

\subsection{Chemical oxygen demand of soap solutions}

In reactive dyeing a large part of total water consumption is used for washing procedure after dyeing. Efficiency of washing procedure after dyeing is related with various parameters such as dye substantivity and diffusion, $\mathrm{pH}$ value, washing agent type and concentration, water hardness and amount of electrolytes in soaping bath. Electrolytes in soaping solution come from salts making water hardness and salts from dyeing process brought with material.

Figure 3 show that with every dyeing, out of five dyes, there was a great removal of dyes during soap treatment because high COD values were found for soap solutions. COD values for soap solutions include contributions of removed dye and auxiliary agent for soap treatment. 

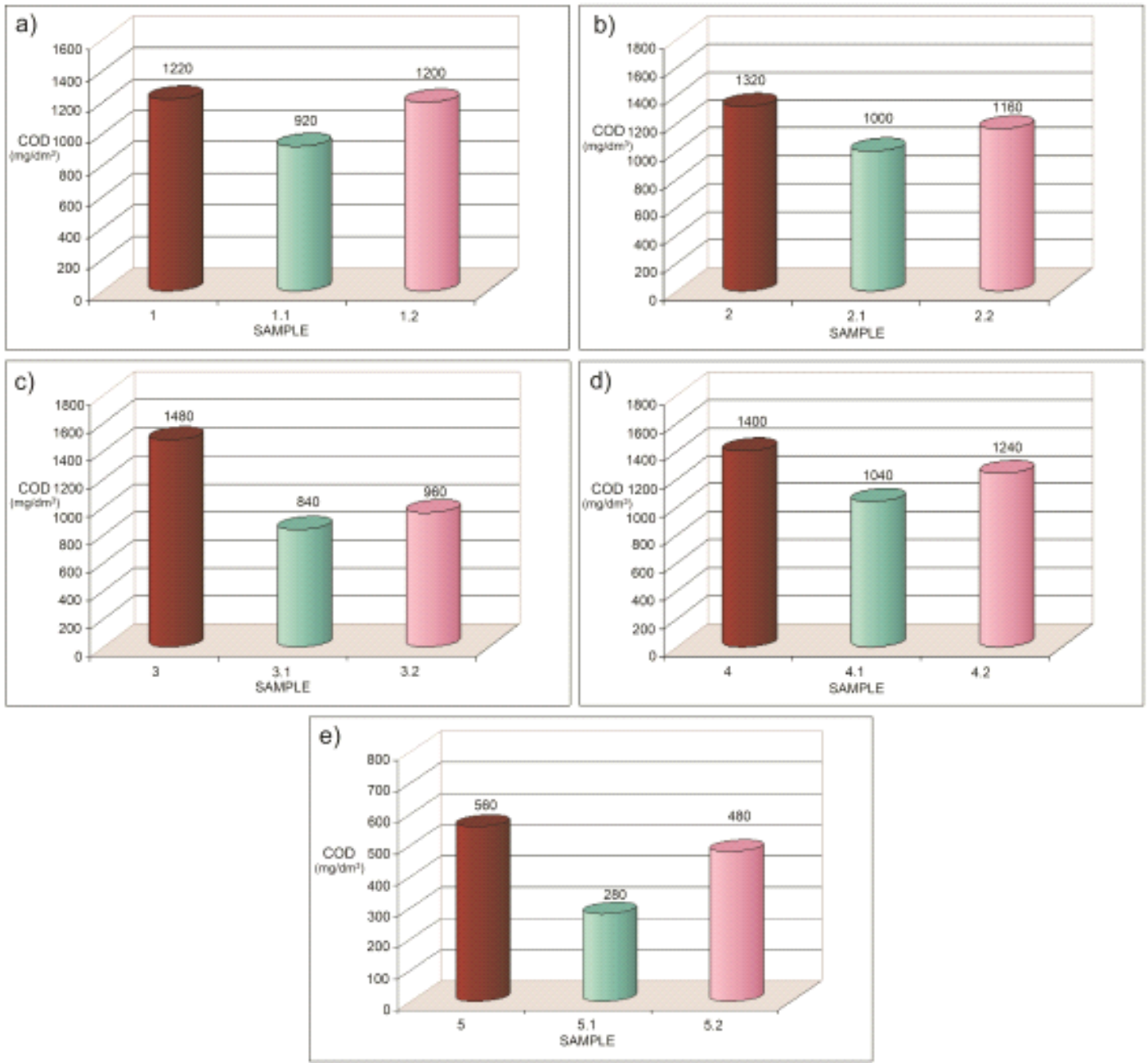

Figure 3. COD values for soap solution with: Bezactive gelb S-3R 150\% (a), Bezactive rot S-3B 150\% (b), Bezactive blau S-GLD 150\% (c), Drimaren brilliant blau K-BL (d) and Drimaren brilliant rot K-BG (e)

Slika 3. HPK vrednosti za sapunski rastvor: Bezaktiv gelb S-3R 150\% (a), Bezaktiv rot S-3B 150\% (b), Bezaktiv blau S-GLD 150\% (c), Drimaren brilliant blau K-BL (d) i Drimaren brilliant rot K-BG (e)

COD value for test formulations with all dyes showed lower values than COD for corresponding standard dyeing and can be attributed to lower electrolyte amount in soap solution brought with the material from the dyeing process. COD decrease with tested reactive dyes depended on dyeing solution formulation and was 12 to $42 \%$ for bifunctional dyes and $11-50 \%$ for monifunctional dyes. Also with soap solutions, higher decrease of COD values was found with samples dyed using the first test formulation where concentration of $\mathrm{NaCl}$ was reduced.

\section{CONCLUSIONS}

In this work, studied was a concept of reduced use of electrolytes in cotton dyeing with reactive dyes that can be applied in practice for the purpose of environmental protection. In alternative procedu- res, instead of addition of full amounts of salts and alkalis, higher dyeing temperature was used to enable sufficient ionization of hydroxyl groups and formation of cell-O ions for covalent fixation of dyes to cotton cellulose. Under the conditions applied in the experiments it is clearly observed that bulkier molecules of bifunctional reactive dyes have lower sensitivity to decreased amounts of electrolyte in dyeing bath, i.e. they show lower changes of color depth compared to monofunctional dyes in relation to the corresponding standard dyeing process.

At higher solution temperatures, fiber capillaries are more open so the molecules pass more easily from one site to another and react with ionized cellulose hydroxyl groups resulting in fast dyeing and high fixation degree as in standard dyeing process. 
From the environmental point of view the procedures are more favorable because bath pollution from dyeing and soap treatment is significantly decreased, which was confirmed by the determination of chemical oxygen demand.

\section{REFERENCES}

[1] D.M.Lewis (2014) Developments in the chemistry of reactive dyes and their application processes, Coloration Technology, 130(6), 382-412.

[2] E.Lau (2001) Sapunjanje kod postupaka bojadisanja reaktivnim bojama, Tekstil, 50(3), 130-133.

[3] A.Khatri, M.H.Peerzada, M.Mohsin, M.White (2015) A review on developments in dyeing cotton fabrics with reactive dyes for reducing effluent pollution, Journal Cleaner Production, 87(1), 50-57.

[4] R.M.El-Shishtawy, Y.A.Youssef, N.S.E.Ahmed, A.A.Mousa (2007) The use of sodium edate in dyeing: II. Union dyeing of cotton/wool blend with hetero bi-functional reactive dyes, Dyes and Pigments, 72(1), 57-65.

[5] S.M.Burkinshaw, O.Kabambe (2011) Attempts to reduce water and chemical usage in the removal of bifunctional reactive dyes from cotton: Part 2 bis(vinyl sulfone), aminochlorotriazine/vinyl sulfone and bis(aminochlorotriazine/vinyl sulfone) dyes, Dyes and Pigments, 88(2), 220-229.

[6] N.Ristić, I.Ristić (2012) Cationic Modification of Cotton Fabrics and Reactive Dyeing Characteristics, Journal of Engineered Fibers and Fabrics, 7(4), 113-121.

[7] N.Ristić, A.M.Grancarić, A.Tarbuk, I.Ristić, M.Šmelcerović (2014) Interface phenomena and dyeability with reactive dyes of cationized cotton, Industria Textila, 65(4), 227-234.
[8] M.J.Mughal, M.Naeem, A.Aleem, R.Saeed, K.Ahmed (2008) Effect of a cationising agent on the conventional reactive dyeing of cotton,Coloration Technology, 124(1), 62-65.

[9] S.M. Burkinshaw, O.Kabambe (2009) Attempts to reduce water and chemical usage in the removal of reactive dyes: Part 1 bis(aminochlorotriazine) dyes, Dyes and Pigments,. 83(3), 363-374.

[10] C.Hessel, C.Allegre, M.Maisseu, F.Charbit, P.Moulin (2007) Guidelines and legislation for dye house effluent, Journal of Environmental Management, 83(2), 171-180.

[11] D.M.Lewis, L.T.T.Vo (2007) Dyeing cotton with reactive dyes under neutral conditions, Coloration Technology, 123(5), 306-311.

[12] S.Šoštar-Turk, R.Schneider, I.Petrinić, R.Fijan (2008) Ekološke alternative $v$ konvencionalnom postopku barvanja z reaktivnimi barvili, Tekstilec, 51(3-4), 122-133.

[13] E.P.Akcakoca, A.T.Ozguney, R.Atav (2007) The efficiency of washing agents in the post-dyeing removal of hydrolyzed reactive dye, Dyes and Pigments, 72(1), 23-27.

[14] S.M. Burkinshaw, O.Kabambe (2011) Attempts to reduce water and chemical usage in the removal of bifunctional reactive dyes from cotton: Part 2 bis(vinyl sulfone), aminochlorotriazine/vinyl sulfone and bis(aminochlorotriazine/vinyl sulfone) dyes, Dyes and Pigments, 88(2), 220-229.

[15] M.Ferus-Comelo (2013) An analysis of the substantivity of hydrolysed reactive dyes and its implication for rinsing processes, Coloration Technology, 129(1), 24-31.

[16] H.H.Knudsen, H.Wenzel (1996) Environmentally friendly method in reactive dyeing of cotton, Water Science and Technology, 33(6), 17-27.

\title{
IZVOD
}

\section{EKOLOŠKE ALTERNATIVE U KONVENCIONALNOM BOJENJU PAMUKA REAKTIVNIM BOJAMA}

Bojenje pamuka najčešće se izvodi reaktivnim bojama, metodom iscrpljenja. Velike količine soli $i$ alkalija koje se koriste u formulaciji kupatila za bojenje dospevaju u vodotokove i negativno deluju na životnu sredinu. $U$ radu je ispitana mogućnost smanjenja koncentracije soli $i$ alkalija u kupatilu za bojenje radi smanjenja zagađenja vode nakon procesa bojenja $i$ sapunske obrade. Dobijeni rezultati pokazuju da su alternativni postupci ekološki povoljniji, što je utvrđeno smanjenim vrednostima hemijske potrošnje kiseonika. Dobiven je visok stepen fiksiranja boja i postojanosti obojenja, dok je intenzitet obojenja neznatno manji u odnosu na standardne uzorke.

Ključne reči: pamuk, reaktivne boje, ekologija, otpadne vode, hemijska potrošnja kiseonika.

\author{
Naučni rad \\ Rad primljen: 24. 07. 2019. \\ Rad korigovan: 23. 10. 2019 \\ Rad prihvaćen: 20. 12. 2019. \\ Rad je dostupan na sajtu: www.idk.org.rs/casopis
}

\footnotetext{
(c) 2020 Authors. Published by Engineering Society for Corrosion. This article is an open access article distributed under the terms and conditions of the Creative Commons Attribution 4.0 International license (https://creativecommons.org/licenses/by/4.0/)
} 